Article

\title{
An Incremental Economic Analysis of Establishing Early Successional Habitat for Biodiversity
}

\author{
Slayton W. Hazard-Daniel ${ }^{1}$ (D) , Patrick Hiesl $^{1}{ }^{\mathbb{C}}$, Susan C. Loeb ${ }^{2}$ and Thomas J. Straka ${ }^{1, *}$ \\ 1 Department of Forestry and Environmental Conservation, Clemson University, Box 340317, Clemson, \\ SC 29634, USA; shazard@g.clemson.edu (S.W.H.-D.); phiesl@clemson.edu (P.H.) \\ 2 USDA Forest Service, Southern Research Station, 233 Lehotsky Hall, Clemson, SC 29634, USA; \\ sloeb@fs.fed.us \\ * Correspondence: tstraka@clemson.edu; Tel.: +1-864-656-4827
}

Received: 6 July 2017; Accepted: 25 September 2017; Published: 28 September 2017

\begin{abstract}
Early successional habitat (ESH) is an important component of natural landscapes and is crucial to maintaining biodiversity. ESH also impacts endangered species. The extent of forest disturbances resulting in ESH has been diminishing, and foresters have developed timber management regimes using standard silvicultural techniques that enhance ESH. We developed a financial framework to evaluate these ESH-enhancing forest management regimes, driven by differences in timber harvest costs and timber revenue. The economic model was applied to on-the-ground prescriptions in the Nantahala National Forest (NNF) designed to increase biodiversity and foster improved public awareness of the importance of ESH. Bats, a current conservation concern, commonly exploit ESH and were the focus of our prescriptions. The prescriptions were based on shelterwood cuts of varying patch size, spacing between the cuts, and the trail area required to move from patch to patch. The results showed that prescriptions with large patch areas were effective in increasing ESH, with minimal impact on the financial performance of timber harvesting operations. This information can be used to minimize financial losses while catering to wildlife species that prefer $\mathrm{ESH}$, in addition to increasing overall biodiversity.
\end{abstract}

Keywords: early successional habitat; biodiversity; bats; economic analysis; forest management; incremental analysis

\section{Introduction}

Early successional habitat (ESH) is an important component of natural landscapes, whether occurring naturally in grasslands and shrublands or due to disturbances within late successional forests [1]. While these ecosystems differ in terms of vegetative composition, they all possess a prominent characteristic of ESH in that they are not dominated by tree canopies, but consist of short herbaceous and woody vegetation [1,2]. The type of disturbance that creates ESH can occur naturally through the actions of wind, insects, or fire and through anthropogenic means such as timber harvesting or climate change-induced clearings in the landscape caused by wind storms that uproot trees or droughts that kill trees [3,4].

ESH is critical to maintaining the diversity of flora and fauna in deciduous forests and has a role in forest dynamics in terms of tree regeneration and the maintenance of disturbance generated plant species [5]. The early stage of succession, with an openness caused by the absence of a closed canopy, harbors more pioneer species of grasses and shrubs that better coexist with some endangered, threatened, or sensitive plant and animal species $[2,6,7]$. The importance of ESH to wildlife is especially well-documented for certain birds [8] and various mammals [9]. 
The loss of old-growth forests and the degradation and fragmentation of second-growth forests are widely recognized conservation problems in North America; not so widely known is the waning of ESHs characterized by young forests [1,2]. Many wildlife species in North America have suffered significant population declines due to habitat loss, especially ESH loss [10-12]. Conservationists and the general public are often disenchanted by the landscapes produced by the human disturbances that favor ESH [1,13]. Clearcutting, for example, is often used to create ESH, but produces results that are sometimes very unpopular with the public, especially environmentalists [14,15].

The extent of forest disturbances and the resulting ESH has been diminished by shifts in agricultural lands, flood control projects, fire suppression, and even by fully-stocked forests that result in less wind-blown trees [1]. Foresters have developed specific management objectives and practices to support plant and animal species that rely on disturbances within a forest, but a number of issues such as a lack of funding, biased public perception, and a lack of clearly stated habitat goals that enhance ESH can hamper the implementation of the objective. Federal and state forestry and wildlife incentive program funding agencies have recognized this problem and have strongly encouraged the development of ESH by private landowners [16].

A standard silvicultural practice used to establish ESH within a forest has been clearcutting, which tends to host few structures of biodiversity importance [17]. Environmentalists have long opposed the practice as extremely detrimental to ecological processes within the forest, creating landscapes considered to be "unimportant" and "unappealing" from an aesthetic and ecological point of view [1]. Forestry and natural resources management professionals have clearly demonstrated the benefits ESH can play within an ecosystem, but its use for conservation purposes is a relatively new idea. However, foresters, wildlife biologists, and conservationists throughout the United States now consider it an increasingly important issue, and set-asides of clearcuts for protection have been shown to be an attractive cost-effective strategy when accounting for the habitat requirements of multiple species $[9,18]$.

The economic cost of establishing ESH management as a conservation technique is not well-known. Timber harvesting costs related to the establishment of ESHs and cost efficiencies due to patch size are rarely quantified $[19,20]$. We describe a financial framework to evaluate the alternative forest management regimes used to establish ESH, primarily driven by differences in timber harvesting cost and timber yield revenues. This model was applied to a number of proposed prescriptions within the Nantahala National Forest (NNF), located in western North Carolina. These prescriptions support increased biodiversity within the forest, as well as better public awareness of the importance of such habitats. Our goal was to provide a better understanding of the economics of ESH as a conservation technique on both private and public lands.

\subsection{Early Successional Habitat and Silviculture}

Forest management practices affect both the edge environment and habitat for forest-dependent interior species [21,22]. Timber harvest is one of the most effective ways to create ESHs in managed forest ecosystems [6], serving to enhance connectivity among disturbed sites and altering the abundance of early successional species at the stand level and the relative abundance of open, edge, and closed forest vegetation at the landscape level [23-25].

Silvicultural systems manipulate variables that can affect ESH, including the selection of patch size, the regeneration cut timing, and even the selection of the rotation age. Silvicultural prescriptions to establish ESH widely vary. One recommendation for birds in the northeastern United States is group selection cuts with patches of at least 0.8 ha generated about every 10 to 15 years and regeneration of trees that are intolerant and mid-tolerant of dramatic changes in stand structure [26]. Another method is to maintain permanent 'wildlife openings' by using prescribed burns or mechanical treatments [27]. Acceptable levels of ESH necessary to sustain wildlife populations will require active intervention and forest management [28]. 
The most effective silvicultural methods for providing ESH are those associated with even-aged management, including clearcut, shelterwood, and seed-tree regeneration methods. While these silvicultural methods differ from each other, they are similar in that each method removes a large amount of timber within a specific forest stand [1-3,29-31]. The literature contains many operational examples of silvicultural applications that apply to establishing ESH $[2,16,26,28,32,33]$.

Clearcutting involves the removal of all trees, usually at the forest stand's economic maturity age, resulting in an even-aged forest and the use of the total ecological space. The method is popular due to its associated simple and cost-effective implementation and high timber yields. The shelterwood method also produces an even-aged stand, but under the protection of older trees. The mature seed-bearing trees can be left to provide cover to environmentally-sensitive areas while the new stand is being established. The seed-tree method leaves only a few trees of the optimum phenotype as a seed source, so its effects are similar to a clearcut [34].

All three silvicultural treatments can provide ESH within a forest. However, parameters such as the size of the cut, the timing of the cut, the period between cuts, and rotation age will impact their effectiveness in producing ESH. In contrast, unevenly aged regeneration methods that produce unevenly aged stands like selection cuts do not remove enough of the overstory to promote vigorous understory growth and do not provide a large enough gap for species that favor ESHs [3]. The three systems vary in terms of the gaps or patches they create in the forest and that is the main variable that controls effectiveness in creating ESH [35].

\subsection{Bat Conservation and Forestry}

Bats provide an example of mammals that commonly exploit ESH and were used in our analysis as a case study to evaluate ESH and various management regimes. Bat populations in the eastern United States are currently experiencing precipitous declines due to white-nose syndrome (WNS), a disease that has killed millions of bats since 2006 [36], and additional stressors, including habitat loss and wind energy development [37]. Knowledge and understanding of habitat use by forest bats in relation to local, stand, and landscape characteristics are critical to bat conservation and management. Especially important is the bats' response to forest management practices like timber harvesting that impact their habitat. Few studies in the southeastern United States have addressed these issues [38,39].

ESHs are important foraging sites for a number of North American bat species as they provide areas with abundant insects and reduced clutter, allowing for unobstructed flight and reduced 'noise' when echolocating [40-42]. For example, six of 15 bat species found in the Central Hardwoods Region [42], three of four bat species groups in Ontario, Canada [43], four of four bat species in the Piedmont of Georgia [44], three of three bat species groups in the managed forests of Ohio [45], and three of seven bat species in the managed forests of Indiana [46] commonly forage in open areas or their edges.

The use of ESH by bats varies due to factors like body size and echolocation call structure, resulting in larger species being more likely to use open areas and smaller species more likely to use interior forests and the interface between mature forest and open areas or edges [47,48]. Tree-fall gaps within mature forests are important foraging sites for a number of bat species $[42,49,50]$, but research is limited on the effects of patch size and isolation on their use $[40,49,51]$. Understanding how factors like size and isolation impact the suitability of ESHs as bat foraging sites allows for the design of timber management activities that better provide for the foraging needs of bats [42].

Bat conservation has recently become a very important topic in forestry due to sharp declines in various bat species throughout North America. In addition, bats provide important ecosystem services in forest and agricultural systems. For example, most bat species within the United States. and Canada are insectivores and are the main predator of 'night-flying insects,' such as beetles and moths, which can cause serious damage to natural and semi-natural open and forest habitats [52].

Management for bats within industrial and investment organization forests has been a concern for conservation efforts. These forests are intensively managed for timber production, and, while wildlife 
values are addressed, the focus is usually on species diversity rather than a single species. These lands are almost all managed under forest certification programs that require wildlife considerations, and bat conservation is certainly one of those considerations. These organizations already use many practices that could encourage bat habitats [53].

While the literature on bats and bat habitat is extensive [26,54], there has been very little focus on the cost of providing for these important mammals. Forest management practices to enhance ESH are common silvicultural options, but, even so, the economics of establishing an ESH for wildlife purposes lacks detailed financial analysis in terms of costs. The purpose of our study was to provide an economic analytical framework of the incremental differences between management regimes creating $\mathrm{ESH}$, using on-the ground NNF prescriptions to evaluate our modeling technique.

\section{Study Area and Methods}

The study area was within the Cheoah Ranger District on the Nantahala National Forest (NNF), North Carolina, USA (Figure 1). Our case study involved the development of silvicultural prescriptions to develop ESH to support wildlife, including various bat species, within the region. The study area consisted of a landscape that supports a diverse bat population [55]. The topography is mountainous and includes areas with steep inclines. This ranger district has a well-developed road system; therefore road development was not a relevant cost in this analysis.

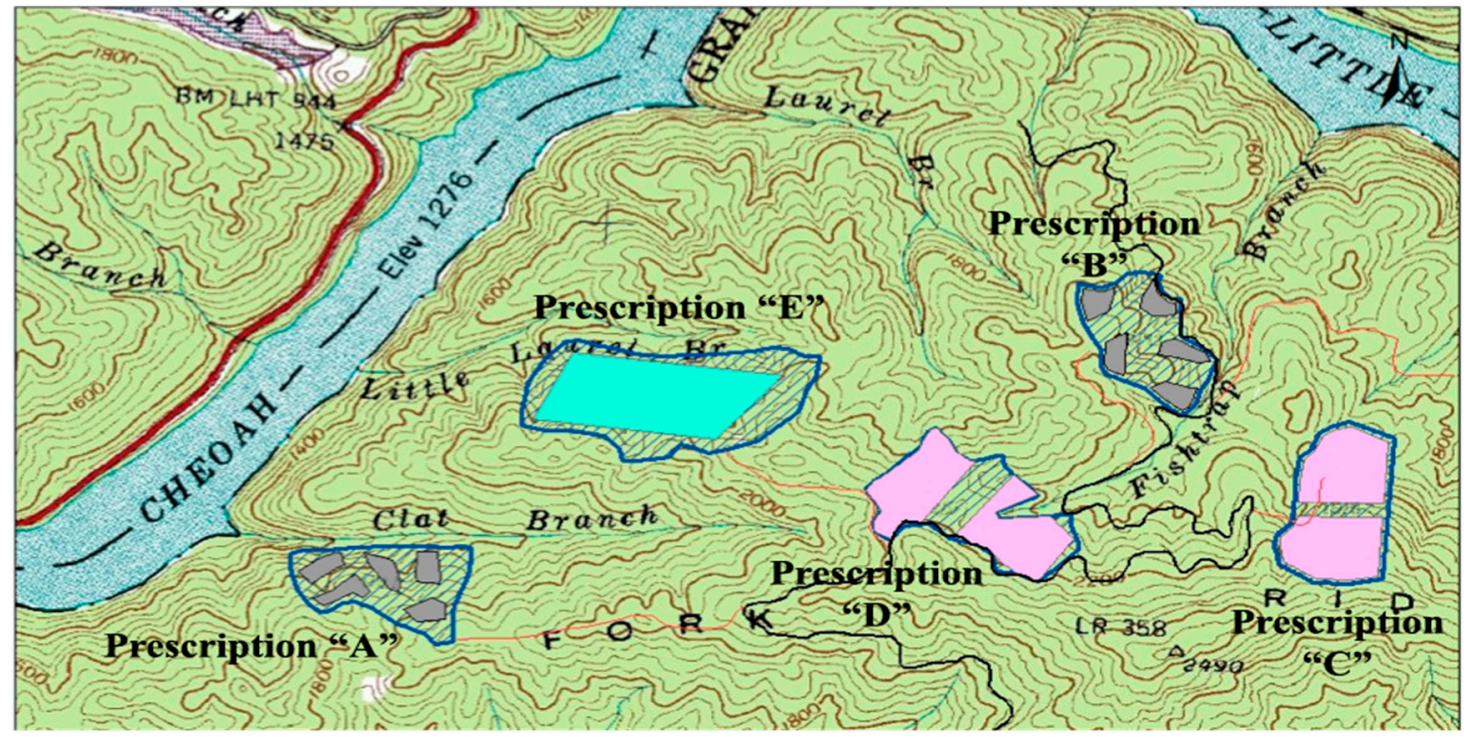

Figure 1. Examples of forest management prescription layouts on the Nantahala National Forest, North Carolina, USA. See Study Area and Methods for a description of the prescriptions.

The timber on the Cheoah Ranger District consists of mixed-hardwood, primarily Southern Appalachian species such as tulip poplar (Liriodendron tulipifera) and white oak (Quercus alba), with some pine cover types. White pine is common in plantation conditions due to management activities during the mid- to late-twentieth century, but it does not represent a significant cover type. Hardwood and hardwood-pine cover types occupy about three-quarters of the ranger district area, with pine and pine-hardwood cover types occupying the remainder [56].

The timber volumes were marginal in terms of producing a profitable financial return from thinnings and harvests. The forest conditions were typical of the region. The forest is currently being managed on a 70 to 90 year cutting cycle. The current management regime involves an herbicide treatment at age five, a pre-commercial thinning at age 15, a commercial thinning at age 40, and a final harvest between years 70 to 90 . Timber in this national forest is seldom clearcut and instead is typically managed with the shelterwood silvicultural system [56]. 


\subsection{Prescriptions}

We conducted an economic analysis of various forest management regimes differentiated between dispersed and aggregated timber harvest alternatives. Our procedure required the development and application of prescriptions on the ground in order to estimate the physical and economic differences between them [57]. We created five management regimes using five varying prescriptions to establish value in enhancing wildlife species within the forest. The five prescriptions, A, B, C, D, and E (Figure 1), were based on the shelterwood silvicultural system, with each a prescription requiring a $10 \%$ retention of the standing timber. To conduct these shelterwood patch cuts with logging equipment, machinery was moved from one patch cut to the other, requiring a trail (about $3.5 \mathrm{~m}$ wide) to be cut. The trail lengths varied from $30 \mathrm{~m}$ (aggregated cuts) to $120 \mathrm{~m}$ (dispersed cuts) depending upon the prescription. The model assumed that all merchantable timber within the trails and shelterwood cuts would be utilized, recognizing, in some situations involving small cuts, that utilization would not be feasible. For each of these prescriptions, the timber yields, management cost, and harvesting cost of the non-traditional prescriptions $(\mathrm{A}, \mathrm{B}, \mathrm{C}$, and $\mathrm{D})$ were compared to those of a more traditional prescription, represented by E.

Prescription A was composed of five individual 0.4 ha cuts spaced $30 \mathrm{~m}$ apart. Prescription B differed from prescription A in that the cuts were spaced $120 \mathrm{~m}$ apart. During implementation, timber from prescriptions A and B was not utilized and instead left as slash (Figure 2). However, our models included both utilization and non-utilization for comparison. Prescriptions $C$ and D were composed of two 3.6 ha cuts spaced 30 or 120 m apart, respectively. Prescription E was a continuous 8.1 ha cut, requiring no trails. Timber was assumed to be utilized in Prescriptions C, D, and E.

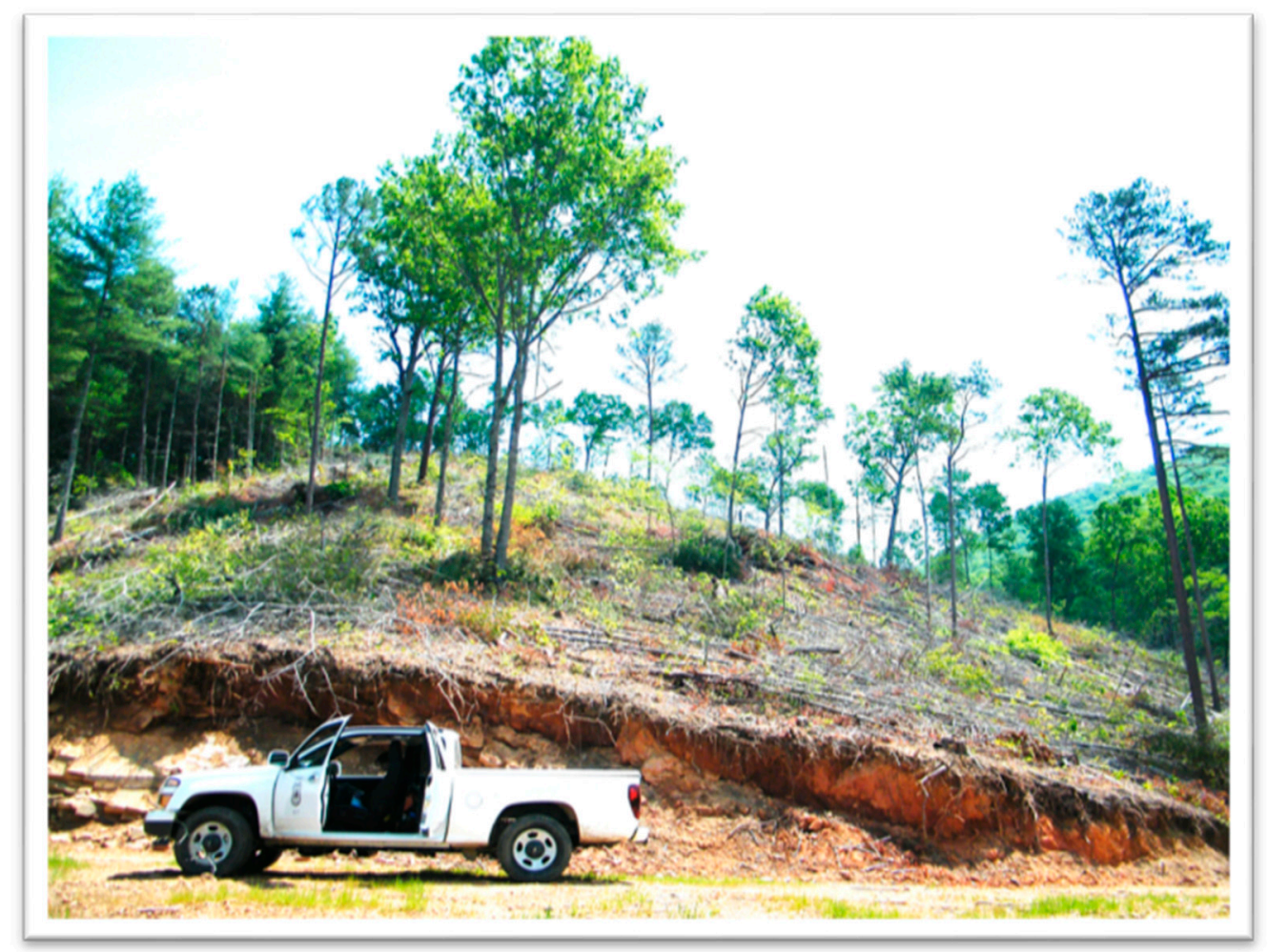

Figure 2. A 0.4 ha patch cut where timber was left as slash on the Nantahala National Forest, North Carolina, USA.

\subsection{Cost and Revenue Relationships}

The costs varied across the prescriptions mainly due to differences in timber harvesting, mainly relating to harvesting machine productivity (which is impacted by timber species, stand composition 
and density, slope, and stem size). The prescriptions affected how efficiently the stands could be harvested, and this had the largest influence on costs. Timber harvesting costs generally decrease with greater average tree diameter, lesser slopes, and greater stand density [58].

The calculation for estimating the cost of cutting trails (TC) within each prescription was primarily based on trail area and the average yield from that area. The trail area in hectares was multiplied by the average yield per hectare to obtain the total timber volume consumed by the trails. This total timber volume multiplied by the harvesting cost per unit of timber volume produced the trail cost. A general description of the parameters used in the cost calculations is presented in Table 1.

Table 1. Descriptions of the five timber harvest prescriptions in terms of the parameters used in the cost calculations to determine the trail area, timber volume in trails, and timber utilization in the Nantahala National Forest, North Carolina, USA.

\begin{tabular}{cl}
\hline Prescription & \multicolumn{1}{c}{ Description of Parameters } \\
\hline A & Five individual 0.4 ha timber cuts spaced $30 \mathrm{~m}$ apart and no timber utilized. \\
B & Five individual 0.4 ha timber cuts spaced $120 \mathrm{~m}$ apart and no timber utilized. \\
C & Two individual 3.6 ha timber cuts spaced $30 \mathrm{~m}$ apart and timber utilized. \\
D & Two individual 3.6 ha timber cuts spaced $120 \mathrm{~m}$ apart and timber utilized. \\
E & Continuous 8.1 ha timber cut, no trails, and timber utilized. \\
\hline
\end{tabular}

The cost of conducting the actual shelterwood or patch cut (SWC) was obtained by multiplying the area of each cut by the average timber yield to calculate the volume of timber within each patch cut:

$$
\mathrm{SWC}=\mathrm{TCA} \times \mathrm{ATY}
$$

where SWC is the shelterwood cut cost, TCA is the timber cut area in ha, and ATY is the average timber yield in tons per ha. This timber volume was reduced by the percentage of retention within each patch cut to obtain the harvested timber volume, which was multiplied by the average cost of (cut and load) harvesting to obtain the SWC. The hauling cost (HC) was calculated by multiplying the average hauling distances to the mill by the transportation cost per $\mathrm{km}$ per ton and multiplying that product by the total tonnage of timber hauled:

$$
\mathrm{HC}=\mathrm{AHD} \times \mathrm{CT}
$$

where $\mathrm{HC}$ is the hauling cost, AHD is the average hauling distance in $\mathrm{km}$, and CT is the cost of transportation in dollars per $\mathrm{km}$ per ton.

The periodic management cost represented practices such as chemical control and precommercial thinning. Herbicide applications remove undesired plant species, and the cost of herbicide treatment was on a per hectare basis. The herbicide or precommercial thinning cost was simply the area treated multiplied by the cost per hectare of conducting the treatment. Three standard forest management practices were applied to all five prescriptions: precommercial thinning (PTC), a cost at year five in the cutting cycle; chemical release (CRC), a cost at year 15 in the cutting cycle; and a commercial thinning (CTR), a revenue at year 40 in the cutting cycle. A standard annual management cost (AMC) was considered in the model. Annual management costs are the only costs that occur every year and were discounted separately due to this temporal difference. The total timber harvesting cost (TTHC) for each prescription involved summing each of the prior component costs:

$$
\mathrm{TTHC}=\mathrm{TC}+\mathrm{SWC}+\mathrm{HC}
$$

where TTHC is the total timber harvesting cost, TC is the cost of cutting the trails, SWC is the cost of conducting the shelterwood or patch cut, and HC is the hauling cost. 
The timber revenue (TR) from each prescription was based upon the average stumpage price within the region multiplied by the timber volume harvested from the prescription area (less timber retained on the site) and included timber harvested from the trails. The trail tonnage was added into the revenue due to the assumption that the merchantable timber cut from the trails would be utilized. Since this timber is managed on a 70-year cutting cycle, cash flows will also occur on that cycle. Thus, a cutting cycle in years (70 years) is used to discount all cash flows, except the annual one. The net revenue (NR) was used in the financial calculations and is TR minus TTHC:

$$
\mathrm{NR}=\mathrm{TR}-\mathrm{TTHC}
$$

where $\mathrm{NR}=$ net revenue, $\mathrm{TR}=$ total revenue, and TTHC $=$ total timber harvesting cost.

\subsection{Financial Parameters}

The economic analysis utilized silvicultural data from the NNF and published Southwide average timber prices and costs in 2013. This is the last year for which complete yield and financial data were available and the year in which harvesting began; inflation has been minimal since 2013 [59]. Fuel consumption of $12 \mathrm{~L} / \mathrm{km}$ on haul trucks and an estimated cut and load-logging rate of $\$ 12.17$ in 2013 were used in the calculations [60]. Loggers in the Southeast traveled an average of $79 \mathrm{~km}$ to reach the mill [58]. The timber yield within the NNF averaged 100.7 tons per hectare [55]. The revenue was based upon the 2013 Southwide mixed-hardwood sawtimber average stumpage price of $\$ 27.58$ per ton [61]. National forests are managed for perpetuity, and the calculations accounted for this assumption at a $\$ 12.36$ per ha annual management cost.

The management costs were relevant to all prescriptions. These estimated costs were $\$ 74.13$ per ha for chemical release at year five, a pre-commercial thinning at year 15 costing $\$ 123.55$ per ha, a commercial thinning at year 40 producing revenue of one-third the final harvest level, and a final harvest at year 70 . Timber harvests within the NNF produced an estimated $\$ 2498.85$ per ha at final harvest [56]. The transportation cost of moving the equipment to the actual site was not included because, operationally, the equipment would already be on site, and cutting within each experimental unit would simply be altered. In terms of incremental analysis, the transportation costs would be identical and could be omitted from the calculation.

The net present value (NPV) is the standard financial criterion to measure the difference between alternatives (such as differing harvest patterns). The incremental approach uses NPV and considers the differences between the prescriptions in terms of cash flows, after factoring in the time value of money. NPV was calculated as if the cutting cycles occurred on a perpetual basis; that is essentially a version of the standard land expectation value or bare land value calculations that is commonly applied in forest valuation [62]. All costs are assumed to be compounded to the end of the cutting cycle and that value is calculated as a perpetual periodic cash flow based on repeated cutting cycles. The general formula for the NPV calculation is:

$$
\mathrm{NPV}=\frac{\mathrm{NR}(1+\mathrm{i})^{\mathrm{C}}+\mathrm{CTR}(1+\mathrm{i})^{\mathrm{C}-\mathrm{Y}}-\sum \mathrm{IC}(1+\mathrm{i})^{\mathrm{C}-\mathrm{Y}}}{(1+\mathrm{i})^{\mathrm{C}}-1}-\frac{\mathrm{AC}}{\mathrm{i}}
$$

where NPV is the net present value, NR is the net revenue at the beginning of cutting cycle, CTR is commercial thinning revenue, IC is the intermediate cost, $\mathrm{C}$ is the cutting cycle length in years, $\mathrm{Y}$ is the year in which intermediate cost occurs in the cutting cycle, and $\mathrm{i}$ is the interest rate, expressed as a decimal.

A $4 \%$ interest rate was used for discounting; this is a real interest rate (net of inflation) and appropriate for an analysis of this type $[63,64]$. The first term on the right side of the equation discounts the revenue and costs compounded to the end of a cutting cycle and converted to a perpetual 
periodic basis, and the second term discounts the annual management cost on a perpetual annual basis [65]. The net present value is given below:

$$
\mathrm{NPV}_{\mathrm{p}}=\left[\frac{\mathrm{NR}(1.04)^{\mathrm{C}}+\mathrm{CTR}(1.04)^{30}-\operatorname{PTC}(1.04)^{55}-\mathrm{CRC}(1.04)^{65}}{(1.04)^{70}-1}\right]-\frac{\mathrm{AMC}}{\mathrm{i}}
$$

where $\mathrm{NPV}_{\mathrm{p}}$ is the net present value for prescription $\mathrm{p}$; $\mathrm{p}$ is equal to $\mathrm{A}, \mathrm{B}, \mathrm{C}, \mathrm{D}$, or $\mathrm{E}$; NR is the net revenue, CTR is the commercial thinning revenue, PTC is the precommercial thinning cost, CRC is the chemical release cost, and AMC is the annual management cost. The future value of one cutting cycle was determined and then put on a perpetual basis. This technique is standard forest valuation practice [62].

\section{Results}

\subsection{Costs and Revenues}

Chainsaws were used on prescription A and B to conduct the 0.40 ha patch cuts at a cost of $\$ 1900$ and $\$ 2700$ per ha, respectively [56]. However, operationally, this harvesting would typically be used as part of the regular harvesting operation using equipment already on site. All timber within the five 0.4 ha patch cuts was felled and left in the patch cuts, with no additional management. Not utilizing the timber resulted in no associated hauling cost, but incurred an opportunity cost for foregone timber revenue of $\$ 5744.07$ for prescription A and $\$ 7796.97$ for prescription B. Of course, some additional value could result from the resulting structural change to habitat, and this opportunity cost could be offset by the ecological benefits provided to wildlife and plants.

The annual management costs varied among treatments because the impacted area varied by prescription. Each prescription had differing trail areas and timber harvest areas (Table 2). Larger prescriptions such as D and $\mathrm{E}$ had greater total area harvested and thus greater management costs than prescriptions with less area (prescriptions A and B).

Table 2. The costs associated with timber harvesting per hectare assuming that all timber was utilized, and trail area and timber volume in trails for five timber harvest prescriptions in the Nantahala National Forest, North Carolina, USA.

\begin{tabular}{|c|c|c|c|c|c|c|}
\hline Prescription & TC (\$) ${ }^{1}$ & SWC (\$) ${ }^{2}$ & $\mathrm{HC}(\$)^{3}$ & TTHC (\$) ${ }^{4}$ & $\mathrm{TA}^{5}$ & TVT $^{6}$ \\
\hline A & 371.66 & 2459.50 & 1481.88 & 4313.04 & 0.28 & 27.7 \\
\hline B & 1481.16 & 2459.50 & 2062.61 & 6003.27 & 1.10 & 110.4 \\
\hline $\mathrm{C}$ & 16.40 & 8854.18 & 4643.03 & $13,513.61$ & 0.01 & 1.2 \\
\hline $\mathrm{D}$ & 60.12 & 8854.18 & 4665.90 & $13,580.20$ & 0.04 & 4.5 \\
\hline $\mathrm{E}$ & 0.00 & 9837.98 & 5149.38 & $14,987.36$ & 0.00 & 0.0 \\
\hline
\end{tabular}
${ }^{1}$ Trail cost, ${ }^{2}$ Shelterwood cut cost, ${ }^{3}$ Hauling cost, ${ }^{4}$ Total timber harvesting cost, ${ }^{5}$ Trail area (ha), and ${ }^{6}$ Timber
volume in trails (tons).

The total costs per hectare for the five prescriptions (including trails) are presented in Table 2. As expected, increased trail area (dispersed cuttings) was associated with a higher per ha total cost. Prescription B required the most area in trails, while prescription A required the second most. Prescription E did not have any costs associated with trails due to it being one continuous 8.1 ha cut. Differences in patch cut cost and hauling cost were dependent upon the amount of timber removed from each prescription.

\subsection{Net Present Value (NPV)}

Prescriptions C, D, and E had the highest NPVs (Table 3). Prescriptions A and B produced the lowest NPVs due to a smaller harvest area with substantial costs. Two factors had the greatest impact on NPV. First, prescriptions varied by trail requirements, and trails represented a substantial cost. Plus, 
trails can have an effect on timber revenue. Second, the harvest area varied by prescription, resulting in a timber yield difference between prescriptions. NPV was largely controlled by the factors that impact the volume of timber produced by the patch or shelterwood cuts and the harvesting cost incurred to obtain that timber, including trails moving from patch to patch. Those are simple factors like size of the patch cuts, spacing between patch cuts, and the trail area required to move from patch to patch. Our results are simply based on the cash flows (costs and revenues) that result from prescription differences that vary due to those factors.

Table 3. The costs and revenues considered in the net present value (NPV) calculation by prescription per hectare, with calculated NPV using a $4 \%$ interest rate for five timber harvest prescriptions in the Nantahala National Forest, North Carolina, USA.

\begin{tabular}{cccccccc}
\hline Prescription & TTR (\$) $^{\mathbf{1}}$ & NTR (\$) $^{\mathbf{2}}$ & CTR (\$) $^{\mathbf{3}}$ & CRC (\$) $^{\mathbf{4}}$ & PTC (\$) $^{\mathbf{5}}$ & AMC (\$) $^{\mathbf{6}}$ & NPV (\$) $^{\mathbf{7}}$ \\
\hline A & 5744.07 & 1431.03 & 472.24 & 170.40 & 284.00 & 28.40 & 606.16 \\
B & 7796.97 & 1793.70 & 592.91 & 231.30 & 385.50 & 38.55 & 653.11 \\
C & $18,233.44$ & 4719.83 & 1557.54 & 540.90 & 901.50 & 90.15 & 2126.65 \\
D & $18,314.34$ & 4734.14 & 1562.27 & 543.30 & 905.50 & 90.55 & 2128.51 \\
E & $20,225.67$ & 5238.31 & 1728.64 & 600.00 & 1000.00 & 100.00 & 2362.19 \\
\hline
\end{tabular}

${ }^{1}$ Total timber revenue from patch cuts and trails, ${ }^{2}$ net revenue after harvesting costs, ${ }^{3}$ commercial thinning revenue, ${ }^{4}$ chemical release cost, ${ }^{5}$ precommercial thinning cost, ${ }^{6}$ annual management cost, and ${ }^{7}$ net present value at a $4 \%$ interest rate.

We noted that Prescriptions A and B might be implemented by conducting the cuts with chainsaws without utilizing the harvested timber. This obviously would reduce NPV from the values in Table 3. Using this assumption with the other standard costs in the analysis, the NPVs of prescriptions A and B were $-\$ 4951.93$ and $-\$ 5913.47$, respectively. The non-utilization of timber represents an opportunity cost, and, perhaps, the ecological benefits of such a cut may reduce these negative NPVs if added to the analysis.

\section{Discussion}

The prescriptions we analyzed and the resulting harvesting scenarios provided a framework to evaluate the opportunity cost of creating ESHs to support wildlife populations such as bats. The main opportunity costs were related to foregone timber revenue, additional trails necessary for the various prescriptions, and differences in patch cut and hauling costs. Close observation of the harvesting patterns, especially distances between the individual cuts, illustrates what drives these cost differences. Some prescriptions require additional trails and harvesting equipment movement; this becomes costly. The results identified the key cost components that impact the financial returns of forest management that creates ESH, and these have useful management implications.

One observation is that the interaction of the silviculturalists and wildlife management professionals is crucial to providing ESHs for the protection of wildlife species [66]. The ESH differences that resulted from the prescriptions did create structural changes to habitats that would influence bat populations. The cost implications of those changes become clearer when component costs are identified and the impacts on NPV are determined. That was the main result of this research, and it will allow wildlife managers to better estimate the opportunity cost of establishing ESHs. Cost factors related to pattern differences interacted to determine the functionality of silvicultural prescriptions in creating viable wildlife habitats related to the elements known to influence endangered species populations like disturbance patterns [67], rotation age [26,68], and edges [69,70]. Often these frameworks are evaluated on a financial basis, and we presented a functional model to perform that type of evaluation.

Our results complement simultaneous research on the NNF that utilized the same ranger district for a study that determined how ESH opening size, the presence of edge, opening shape, prey abundance, vegetation structure, and environmental factors affect bat activity [55]. That study 
concluded that, in the southern Appalachian Mountains, opening size did not affect bat activity, but that forest managers creating ESH to benefit bats should focus on maintaining an open vegetation structure, configure openings to maximize edge relative to opening area, and create openings at lower elevations [55]. Our results add an economic context to that related research and would aid in addressing the cost-effectiveness of implementing those recommendations.

Different cost interactions between each silvicultural prescription rely on a number of key parameters. The distance between each cut and the cut size are primary factors that affect the cost of implementing prescriptions. As the area of the trails increased, so did the per ha cost of conducting the cuts, most likely as a result of increased amounts harvesting equipment moved between smaller cuts. Minimizing the trail area reduces the overall harvesting costs.

Dispersed cuts (prescriptions B and D) reduced the financial viability, mainly due to increased harvesting costs resulting from additional trail area. Prescription E, with the highest total harvest area, benefitted financially from the absence of trails. This dispersal pattern is the fundamental factor that separated prescriptions B and D from the less dispersed prescriptions in terms of NPV.

Prescriptions A and B effectively produced smaller tracts to harvest with less overall harvested timber. In contracting logging operation, no bids were received from private logging companies to carry out prescriptions A and B, demonstrating their reluctance to cut small tracts of land [56]. Economies of scale, both in terms of reducing operational costs and increasing revenue, play a large role in determining financial expediency in timber harvesting operations [71,72]. These economies of scale played a large role in determining the NPV of the harvesting options.

Prescriptions C and D are financially feasible alternatives to increase ESHs in the forest and may be more effective in supporting wildlife such as birds [9], although the effects of cut size on amphibians and reptiles are unknown [73]. The activity of bats in this area did not vary with patch size [55], showing that feasible options for the current forest management regime exist.

The NPVs were based on a 70-year cutting cycle, and it is likely that higher NPVs could be obtained using shorter cutting cycles like those used in commercial timber production. However, since the prescriptions produced similar NPVs, shortened timber rotations would be expected to produce an equivalent ranking of management alternatives.

Studies of state natural resource agencies in the northeastern United States found timber harvesting to be an important tool to promote ESH and suggested increasing its use in developing ESH through alternatives that employ cost-effective management techniques [16,28]. Our research demonstrates a cost-effective technique that created various sized patches or gaps after timber harvest, and patch size has been shown to be crucial for some endangered species $[1,6,10,26]$.

Operationally, the creation of these patches via timber harvest depends on forest landowner resources and objectives, and the variability of timber harvesting costs in patch development will determine the viability of this option [74]. We addressed this variability and identified factors that impacted these costs. More importantly, we actually estimated the costs of these options, and, while the relationship between timber harvesting patterns and timber harvesting costs is well known, few studies have addressed the actual estimated costs of establishing the patterns [75,76].

The management implications of these results are practicable. The management guidelines for establishing ESH commonly discuss creating small gaps in the forest, logging and timber harvesting obstacles to accomplishing that, and cost limitations that limit harvesting options [46,77,78]. Our study provided cost estimates of those limitations. These cost considerations and relationships are common to many discussions of creating ESH in terms of gaps and patches; our contribution is on-the-ground estimates of the actual costs that drive those relationships $[79,80]$.

We have discussed forest management options to create ESH and identified the opportunity cost related to dispersion patterns. Wildlife managers will have to weigh these costs against the incremental value or benefit to wildlife. Often these decisions are based on benefit/cost analyses, and these opportunity costs are relevant parts of the discussion. A better understanding of the cost structure of creating ESH will allow for more effective preparation in the natural resource 
planning decision-making process and should allow for limited resources to be best-utilized to protect endangered and threatened species.

Acknowledgments: This work was funded by USDA NIFA Grant 10882901 and the USDA Forest Service Southern Research Station. We thank S. Bridges for providing data and support throughout this project. We thank C. Post for comments on an earlier draft of this manuscript.

Author Contributions: This study served as Slayton W. Hazard-Daniel's thesis topic, and he designed the study, performed the analysis, and wrote the article. It was conceived by thesis committee members Susan C. Loeb and Thomas J. Straka (committee chair), who provided guidance and supervision. Patrick Hiesl provided significant guidance in the area of forest operations and timber harvesting.

Conflicts of Interest: The authors declare no conflicts of interest.

\section{References}

1. Askins, R.A. Sustaining biological diversity in early successional communities: The challenge of managing unpopular habitats. Wildl. Soc. Bull. 2001, 29, 407-412.

2. Swanson, M.E.; Franklin, J.F.; Beschta, R.L.; Crisafulli, C.M.; DellaSala, D.A.; Hutto, R.L.; Lindenmayer, D.B.; Swanson, F.J. The forgotten stage of forest succession: Early-successional ecosystems on forest sites. Front. Ecol. Environ. 2011, 9, 117-125. [CrossRef]

3. Thompson, F.R., III; Dessecker, D.R. Management of Early-Successional Communities in Central Hardwood Forests: With Special Emphasis on the Ecology and Management of Oaks, Ruffed Grouse, and Forest Songbirds; General Technical Report NC-195; USDA Forest Service, North Central Experiment Station: St. Paul, MN, USA, 1997.

4. Monzón, J.; Moyer-Horner, L.; Palamar, M.B. Climate change and species range dynamics in protected areas. BioScience 2011, 61, 752-761. [CrossRef]

5. Brawn, J.D.; Robinson, S.K.; Thompson, F.R., III. The role of disturbance in the ecology and conservation of birds. Ann. Rev. Ecol. Syst. 2001, 32, 251-276. [CrossRef]

6. Thompson, F.R., III; DeGraaf, R.M. Conservation approaches for woody, early successional communities in the eastern United States. Wildl. Soc. Bull. 2001, 29, 483-494.

7. Hagan, J.M.; Whitman, A.A. Biodiversity indicators for sustainable forestry: Simplifying complexity. J. For. 2006, 104, 203-210.

8. Dettmers, R. Status and conservation of shrubland birds in the northeastern US. For. Ecol. Manag. 2003, 185, 81-93. [CrossRef]

9. Fuller, T.K.; DeStefano, S. Relative importance of early-successional forests and shrubland habitats to mammals in the northeastern United States. For. Ecol. Manag. 2003, 185, 75-79. [CrossRef]

10. Hunter, W.C.; Buehler, D.A.; Canterbury, R.A.; Confer, J.L.; Hamel, P.B. Conservation of disturbance-dependent birds in eastern North America. Wildl. Soc. Bull. 2001, 29, 440-455.

11. Litvaitis, J.A. Importance of early successional habitats to mammals in eastern forests. Wildl. Soc. Bull. 2001, 29, 466-473.

12. Morrison, M.L.; Mathewson, H.A. (Eds.) Wildlife Habitat Conservation: Concepts, Challenges, and Solutions; Johns Hopkins University Press: Baltimore, MD, USA, 2001.

13. Enck, J.; Odato, M. Public attitudes and affective beliefs about early- and late-successional stages of the Great Norther Forest. J. For. 2008, 106, 388-395.

14. Litvaitis, J.A.; Wagner, D.L.; Confer, J.L.; Tarr, M.D.; Snyder, E.J. Early-successional forests and shrub-dominated habitats: Land-use artifact or critical community in the northeastern United States. Northeast Wildl. 1999, 54, 101-118.

15. Gobster, P.H. Human dimensions of early successional landscapes in the eastern United States. Wildl. Soc. Bull. 2001, 29, 474-482.

16. Oehler, J.D. State efforts to promote early-successional habitats on public and private lands in the northeastern United States. For. Ecol. Manag. 2003, 185, 169-177. [CrossRef]

17. Lindström, J.; Öhman, K.; Perhans, K.; Rönnqvist, M.; Gustafsson, L. Cost-effective age structure and geographical distribution of boreal forest reserves. J. Appl. Ecol. 2011, 48, 133-142. [CrossRef] [PubMed]

18. Mazziotta, A.; Pouzols, F.M.; Mönkkönen, M.; Kotiaho, J.S.; Strandman, H.; Moilanen, A. Optimal conservation resource allocation under variable economic and ecological time discounting rates in boreal forest. J. Environ. Manag. 2016, 180, 366-374. [CrossRef] [PubMed] 
19. Wilcove, D.S.; Lee, J. Using economic and regulatory incentives to restore endangered species: Lessons learned from three new programs. Biol. Conserv. 2004, 18, 639-645. [CrossRef]

20. Hummel, S.; Calkin, D.E. Cost of landscape silviculture for fire and habitat management. For. Ecol. Manag. 2005, 207, 385-404. [CrossRef]

21. Chen, J.; Franklin, J.F.; Spies, T.A. Vegetation responses to edge environments in old-growth Douglas-fir forests. Ecol. Appl. 1992, 2, 387-396. [CrossRef] [PubMed]

22. Bannerman, S. Biodiversity and Interior Habitats: The Need to Minimize Edge Effects; Extension Note 21; British Columbia Ministry of Forestry, Research Branch: Victoria, BC, Canada, 1998.

23. Askins, R.A.; Zuckerberg, B.; Novak, L. Do the size and landscape context of forest openings influence the abundance and breeding success of shrubland songbirds in southern New England? For. Ecol. Manag. 2007, 250, 137-147. [CrossRef]

24. Long, J.N. Emulating natural disturbance regimes as a basis for forest management: A North American view. For. Ecol. Manag. 2009, 257, 1868-1873. [CrossRef]

25. Tavernia, B.G.; Nelson, M.D.; Garner, J.D.; Perry, C.H. Spatial characteristics of early successional habitat across the Upper Great Lakes states. For. Ecol. Manag. 2016, 372, 164-174. [CrossRef]

26. DeGraaf, R.M.; Yamasaki, M. Options for managing early-successional forest and shrubland bird habitats in the northeastern United States. For. Ecol. Manag. 2003, 185, 179-191. [CrossRef]

27. Chandler, R.B.; King, D.I.; Chandler, C.C. Effects of management regime on the abundance and nest survival of shrubland birds in wildlife openings in northern New England, USA. For. Ecol. Manag. 2009, 258, 1669-1676. [CrossRef]

28. Brooks, R.T. Abundance, disturbance, trends, and ownership patterns of early-successional forests in the northeastern Unites States. For. Ecol. Manag. 2003, 185, 65-74. [CrossRef]

29. Swanson, F.J.; Franklin, J.F. New forestry principles from ecosystem analysis of Pacific Northwest forests. Ecol. Appl. 1992, 2, 262-274. [CrossRef] [PubMed]

30. Bliss, J.C. Public perceptions of clearcutting. J. For. 2000, 98, 4-9.

31. Greenberg, C.H.; Collins, B.S.; Thompson, F.R., III; McNab, W.H. (Eds.) Introduction: What are early successional habitats, why are they important, and how can they be sustained? In Sustaining Young Forest Communities: Ecology and Management of Early Successional Habitat in the Central Hardwood Region, USA; Springer: New York, NY, USA, 2011; pp. 1-10.

32. King, D.I.; Schlossberg, S. Synthesis of the conservation value of the early-successional stage in forests of eastern North America. For. Ecol. Manag. 2014, 324, 186-195. [CrossRef]

33. Thompson, F.R., III; Probst, J.R.; Raphael, M.G. Impacts of silviculture: Overview and management implications. In Ecology and Management of Neotropical Migratory Birds: A Synthesis and Review of Critical Issues; Martin, T.E., Finch, D.M., Eds.; Oxford University Press: New York, NY, USA, 1995; pp. 201-219.

34. Nyland, R.D. Silviculture: Concepts and Applications, 3rd ed.; Waveland Press: Long Grove, IL, USA, 2016.

35. Guldin, J.M.; Emmingham, W.H.; Carter, S.A.; Saugey, D.A. Silvicultural practices and management of habitat for bats. In Bats in Forests: Conservation and Management; Lacki, M.J., Hayes, J.P., Kurta, A., Eds.; The Johns Hopkins University Press: Baltimore, MD, USA, 2007; pp. 177-205.

36. Frick, W.F.; Puechmaille, S.J.; Willis, C.K.R. White-nose syndrome in bats. In Bats in the Anthropocene: Conservation of Bats in a Changing World; Voight, C.C., Kingston, T., Eds.; Springer: Cham, Switzerland, 2016; pp. 245-262.

37. O'Shea, T.J.; Cryan, P.M.; Hayman, D.T.S.; Plowright, R.K.; Streicker, D.G. Multiple mortality events in bats: A global review. Mamm. Rev. 2016, 46, 175-190. [CrossRef]

38. Loeb, S.C.; O'Keefe, J.M. Habitat use by forest bats in South Carolina in relation to local, stand, and landscape characteristics. J. Wildl. Manag. 2006, 70, 1210-1218. [CrossRef]

39. Brooks, R.T. Habitat-associated and temporal patterns of bat activity in a diverse forest landscape of southern New England, USA. Biodivers. Conserv. 2009, 18, 529-545. [CrossRef]

40. Grindal, S.D.; Brigham, R.M. Short-term effects of small-scale habitat disturbance on activity by insectivorous bats. J. Wildl. Manag. 1998, 62, 996-1003. [CrossRef]

41. Ford, W.M.; Menzel, J.M.; Menzel, M.A.; Edwards, J.W.; Kilgo, J.C. Presence and absence of bats across habitat scales in the Upper Coastal Plain of South Carolina. J. Wildl. Manag. 2006, 70, 1200-1209. [CrossRef] 
42. Loeb, S.C.; O'Keefe, J.M. Bats and gaps: The role of early successional patches in the roosting and foraging ecology of bats. In Sustaining Young Forest Communities: Ecology and Management of Early Successional Habitat in the central Hardwood Region, USA; Greenberg, C.H., Collins, B.S., Thompson, F.R., III, Eds.; Springer: New York, NY, USA, 2011; pp. 167-189.

43. Jantzen, M.K.; Fenton, M.B. The depth of edge influence on insectivorous bats at forest-field interfaces. Can. J. Zool. 2013, 91, 187-192. [CrossRef]

44. Ellis, A.M.; Patton, L.L.; Castleberry, S.B. Bat activity in upland and riparian habitats. Proc. Ann. Conf. SEAFWA 2002, 56, 210-218.

45. Silvis, A.; Gehrt, S.D.; Williams, R.A. Effects of shelterwood harvest and prescribed fire in upland Appalachian hardwood forests on bat activity. For. Ecol. Manag. 2016, 360, 205-212. [CrossRef]

46. Sheets, J.J.; Duchamp, J.E.; Caylor, M.K.; D'Acunto, L.; Whitaker, J.O., Jr.; Brack, V., Jr.; Sparks, D.W. Habitat use by bats in two Indiana forests prior to silvicultural treatments for oak regeneration. In The Hardwood Ecosystem Experiment: A Framework for Studying Responses to Forest Management; General Technical Report NRS-P-108; Swihart, R.K., Saunders, M.R., Kalb, R.A., Haulton, G.S., Michler, C.H., Eds.; USDA Forest Service, Northern Research Station: Newtown Square, PA, USA, 2013; pp. 203-217.

47. Owen, S.F.; Menzel, M.A.; Edwards, J.W.; Ford, W.M.; Menzel, J.M.; Chapman, B.R.; Wood, P.B.; Miller, K.V. Bat activity in harvested and intact forest stands in the Allegheny Mountains. North. J. Appl. For. 2004, 21, 154-159.

48. Morris, A.D.; Miller, D.A.; Kalcounis-Rueppell, M.C. Use of forest edge by bats in a managed pine forest landscape. J. Wildl. Manag. 2010, 74, 26-34. [CrossRef]

49. Menzel, M.A.; Carter, T.C.; Menzel, J.M.; Ford, W.M.; Chapman, B.R. Effects of group selection silviculture in bottomland hardwoods on the spatial activity patterns of bats. For. Ecol. Manag. 2002, 162, 209-218. [CrossRef]

50. Hayes, J.P.; Loeb, S.C. The influences of forest management on bats in North America. In Bats in Forests: Conservation and Management; Lacki, M.J., Hayes, J.P., Kurta, A., Eds.; Johns Hopkins University Press: Baltimore, MD, USA, 2007; pp. 207-235.

51. Fukui, D.; Hirao, T.; Murakami, M.; Hirakawa, H. Effects of treefall gaps created by windthrow on bat assemblages in a temperate forest. For. Ecol. Manag. 2011, 261, 1546-1552. [CrossRef]

52. Kunz, T.H.; Braum de Torrez, E.; Bauer, D.; Lobova, T.; Fleming, T.H. Ecosystem services provided by bats. Ann. N. Y. Acad. Sci. 2011, 1223, 1-38. [CrossRef] [PubMed]

53. Russo, D.; Cistrone, L.; Garonna, A.P.; Jones, G. Reconsidering the importance of harvested forests for the conservation of tree-dwelling bats. Biodivers. Conserv. 2010, 19, 2501-2515. [CrossRef]

54. Acuña, M.P.; Estades, C.F. Plantation clearcut size and the persistence of early-successional wildlife populations. Biol. Conserv. 2011, 144, 1577-1584. [CrossRef]

55. Brooks, J.D.; Loeb, S.C.; Gerard, P.D. Effect of forest opening characteristics, prey abundance, and environmental factors on bat activity in the Southern Appalachians. For. Ecol. Manag. 2017, 400, $19-27$. [CrossRef]

56. Bridges, S. (USDA Forest Service, Nantahala National Forest, NC, USA). Personal communication, 2016.

57. Hazard-Daniel, S.W. Establishing Early Successional Habitat Management Regimes for Enhancing Endangered Wildlife Species: A Marginal Economic Analysis Approach. Master's Thesis, Clemson University, Clemson, SC, USA, 2016.

58. Hiesl, P.; Benjamin, J.G. Applicability of international harvesting equipment productivity studies in Maine, USA: A literature review. Forests 2013, 4, 898-921. [CrossRef]

59. United States Department of Labor, Bureau of Labor Statistics. Consumer Price Index. Available online: https: / /www.bls.gov / cpi/\#tables (accessed on 24 September 2017).

60. Baker, S.; Greene, D.; Harris, T.; Mei, R. Regional Cost Analysis and Indices for Conventional Timber Harvesting Operations; Final Report to the Wood Supply Research Institute, Center for Forest Business; University of Georgia: Athens, GA, USA, 2013.

61. Timber Mart-South. Timber Mart-South Market News Quarterly; University of Georgia: Athens, GA, USA, 2013.

62. Straka, T.J.; Bullard, S.H. Land expectation value calculation in timberland valuation. Appraisal J. 1996, 64, 399-405.

63. Bright, G. Calculating costs and charges for forest machinery use. Forestry 2004, 77, 75-84. [CrossRef] 
64. Straka, T.J. Forest products financial decisions: Inflation in investment analysis. For. Prod. Equip. 2005, 13, 33-35.

65. Bullard, S.H.; Straka, T.J. Basic Concepts in Forest Valuation and Investment Analysis, 3rd ed.; Forestry Suppliers, Inc.: Jackson, MS, USA, 2011.

66. May, H.L. Managing Forests for Fish and Wildlife; Fish and Wildlife Habitat Management Leaflet Number 18; U.S. Department of Agriculture, Natural Resources Conservation Service: Washington, DC, USA, 2002.

67. Warren, S.D.; Büttner, R. Restoration of heterogeneous disturbance regimes for the preservation of endangered species. Ecol. Restor. 2014, 32, 189-196. [CrossRef]

68. Honnay, O.; Hermy, M.; Coppin, P. Effects of area, age, and diversity of forest patches in Belgium on plant species richness, and implications for conservation and reforestation. Biol. Conserv. 1999, 87, 75-84. [CrossRef]

69. Harris, L.D. Edge effects and conservation of biotic diversity. Conserv. Biol. 1988, 2, 330-332. [CrossRef]

70. Fischer, J.; Lindenmayer, D.B. Landscape modification and habitat fragmentation: A synthesis. Glob. Ecol. Biogeogr. 2007, 16, 265-280. [CrossRef]

71. Row, C. Economies of tract size in timber growing. J. For. 1978, 76, 576-582.

72. Gustafson, E.J. Expanding the scale of forest management: Allocating timber harvests in time and space. For. Ecol. Manag. 1996, 87, 27-39. [CrossRef]

73. Moorman, C.E.; Russell, K.R.; Greenberg, C.H. Reptile and amphibian response to hardwood forest management and early successional habitats. In Sustaining Young Forest Communities: Ecology and Management of Early Successional Habitats in the Central Hardwood Region, USA; Greenberg, C.H., Collins, B.S., Thompson, F.R., III, Eds.; Springer: New York, NY, USA, 2011; pp. 191-208.

74. Trani, M.K.; Brooks, R.T.; Schmidt, T.L.; Rudis, V.A.; Gabbard, C.M. Patterns and trends of early successional forests in the eastern United States. Wildl. Soc. Bull. 2001, 29, 413-424.

75. Kittredge, D.B.; Mauri, M.J.; McGuire, E.J. Decreasing woodlot size and the future of timber sales in Massachusetts: When is an operation too small? North. J. Appl. For. 1996, 13, 96-101.

76. Summerville, K.S.; Crist, T.O. Effects of timber harvest on forest Lepidoptera: Community, guild, and species responses. Ecol. Appl. 2002, 12, 820-835. [CrossRef]

77. Tarr, M. Case study: Creating early-successional habitat on a small woodlot in southeastern New Hampshire. In Managing Grasslands, Shrublands and Young Forests for Wildlife: A Guide for the Northeast; Oehler, J.D., Covell, D.F., Capel, S., Long, S., Eds.; Massachusetts Division of Fisheries and Wildlife, Northeast Upland Habitat Technical Committee: Westboro, MA, USA, 2006; pp. 105-109.

78. Smetzer, J.R.; King, D.I.; Schlossberg, S. Management regime influences shrubland birds and habitat conditions in the Northern Appalachians. J. Wildl. Manag. 2014, 78, 314-324. [CrossRef]

79. Coates, K.D.; Burton, P.J. A gap-based approach for development of silvicultural systems to address ecosystem management objectives. For. Ecol. Manag. 1997, 99, 337-354. [CrossRef]

80. Buffum, B.; Modisette, C.; McWilliams, S.R. Encouraging family forest owners to create early successional wildlife habitat in southern New England. PLoS ONE 2014, 9, e89972. [CrossRef] [PubMed]

(C) 2017 by the authors. Licensee MDPI, Basel, Switzerland. This article is an open access article distributed under the terms and conditions of the Creative Commons Attribution (CC BY) license (http:/ / creativecommons.org/licenses/by/4.0/). 